Ali Abdallah

Department of International Tourism Management, Stenden University, Qatar, Doha UDC 005.94:338.48

\title{
GUEST SPEAKERS AND INTERNATIONALISATION IN HIGHER EDUCATION: A CRITICAL REFLECTION OF GUEST SPEAKERS IN TOURISM PROGRAMMES
}

\begin{abstract}
At its general term, this paper discusses the role of guest lecturers in higher education. More precisely, the paper considers the role of guest lecturers in Tourism Management programmes taught to student in Universities. The paper examines theory and literature relating to tourism studies and higher education in general. It discusses the relevance of guest speakers in universities and examines their contributions towards tourism programmes. The paper discusses lecturers in tourism degrees suggesting that they might lack industry experiences but are still required to deliver theories to students and are seen as classroom managers and student mentors. The paper further investigates how lecturers and guest speakers are perceived as two
\end{abstract}

\section{Introducton}

Lectures are an essential element of higher education due to the challenging forces of economic competency, institutional apathy or simply just personal habits (Huxham, 2005). Lectures reach large numbers of students and deliver hefty amounts of material in a short period of time and are therefore popular in academic departments (Huxham, 2005). On the contrary, Bligh (1998) argues that lecturers are being criticized for their humble method of encouraging thoughts and altering student attitudes. Bligh (1998) further argues that students in higher edu- different entities by students where lecturers are seen as classroom managers and guest speakers are seen as the industry knowledge providers. As internationalisation of education becomes the focus of higher education institutions that aim to deliver education in a more international context, guest speakers that address local practical occurrences become less appealing. With the rapid spread of distant learning and online education, the paper concludes that guest lecturers are not the solution for perfect academic experiences in higher education in general and specifcally in tourism programmes.

Keywords: guest speakers, higher education, internationalisation

cation have verified their feelings against such a mode of delivery by not going to their lectures (Bligh, 1998). Similarly, Reece and Walker (2001) suggest that the biggest difficulty and challenge that lecturers face is the passiveness of students in classrooms but also suggests that lectures are still providing the essential learning foundation that students require (Reece and Walker, 2001).

Additionally, in relation to Tourism studies in higher education, Ladkin and Weber (2008) suggest that lecturers that have joined the academic world in the past ten years hold very minimal experience in the tourism industry, usually have two to three 
years' experience and often join academia by internship programmes. Consequently, and as stated by Malley (1997), students studying tourism management degrees usually graduate in their undergraduate degrees, and then complete a Master and Doctoral degree without gaining considerable industry experience in the industry. For students studying tourism management degrees in higher education, the key drive of higher education is serving the tourism industry by graduating proficient and competitive workforces (Shea and Roberts, 2010). Johanson (2010) argues that the enduring feasibility of the tourism industry is reliant on the capability of its management in providing substantial return on investment within a multitude of parameters. Johanson (2010) further suggests that fresh graduates in tourism management should at least encompass a very basic understanding of producing good results in a stressful environment.

The literature discussed above provides a clear image of lecturers in higher education. Lecturers are valuable but might not be appreciated by students due to their teaching styles and methods. In tourism degrees, lecturers might lack industry experiences but are still required to deliver theories to students. So why and how are guest speakers used in higher education, specifically in tourism management programmes?

\section{Lecturers in higher education}

University lecturers are seen as appropriate and valued tools that provide essential knowledge to students (Payne, 2003). Students recognize theory as an opposite of reality because they may not predict how theory can be engrained into reality. Bacon and Novotny (2002) argue that students might have difficulties understanding theories and might not find them thrilling, and therefore do not interact with them. According to Heylings and Tariq (2001), lecturers imple- ment teaching methods that involve workshops and discussions. The authors state that lecturers assess course requirements and provide them accordingly. Byrne (2002) suggests that lecturers crucially understand the learning behaviours of students which lead to the development of teaching strategies that improve student experience. Charlton (2006) argues that despite the availability of inexpensive and more suitable alternative qualifications from reputable distance learning institutions which have grown-up to exploit new communication technologies as they were invented, students still prefer lecture-based teaching. Charlton (2006) further suggests that lecturers are effective due to their being an important aspect of spoken communication that gets delivered to students by a visible person which they can directly interact with. Charlton then states that lecturers improve student learning as they create a formally-structured social event that fits human nature and operates human psychology. Moreover, Crosby (2000) suggests that lecturers act as role models to students by fulfilling their roles as teachers in the classrooms. The author further suggests that the lecturer has an exceptional opportunity to share some of the" magic", as he describes it, of the subject with the students. Crosby (2000) concludes that the lecturer is no longer seen mainly as a distributor of information or a walking tape recorder, but rather as a facilitator or manager of the students' learning.

\section{Tourism programmes in higher education}

According to Ntuli (2007) tourism management graduates are expected to find employment as soon as they graduate, but many cannot. Ntuli (2007) argues that there is a wave on the labour market between skill shortages and unemployed high numbers of graduates. Ntuli (2007) blames 
the high number of unemployed graduates in the tourism industry to the lack of employability skills. Coll and Zegwaard (2006) state that "analytical skills" are required to employ graduates. Barrie (2006) explains how students are usually not ready for the workplace, as indicated by many employers, and advices universities to deliver more employable graduates by providing them with the skills required for their careers. Moss and McKellan (2007) argue that student's knowledge on the subject in general is often acceptable and suggest that if student's competency skills are developed in universities, then they would become much more employable. Yorke and Harvey (2005) suggest that employers expect graduate students to be ready to work after graduating and demand a set of skills from them in order to employ them. The authors then state that universities should offer this set of skills to students and prepare them for real life experiences before they graduate.

Moreover, Hodges and Burchell (2003) referred to "work integrated programmes" and suggested that these programmes are aimed at preparing students to work and provide them with competency skills that employers require. The authors argue that "work integrated programmes" should include technical skills that are an outcome of a programme and not simply skills that students can demonstrate in class. Hodges and Burchell (2003)'s suggestion relates directly to tourism management as the nature of this degree requires certain set of skills that could be applied in a workplace.

According to Crebert (2004), universities that offer tourism management contain the facilities that permit technical skills to be taught to students and applied in workplaces. Fleming and Eames (2005) explain how skills taught to students in universities through work integrated learning can be applied to work environments by obligating students to perform a compulsory semester at a real work place. Warysazak (1999) similarly illustrates the latter by explaining how students that spend time in real life situations get the opportunities required to apply theoretical concepts that they learn in classrooms. Tovey (2001) approaches this concept in a similar, but more interesting manner by stating that students can apply the skills gained in the classroom to a real life situation in the workplace rather than role playing or being told about experiences in a classroom.

\section{Guest speakers in higher education}

Guest speakers are a very essential tool for developing student leaning and improving student engagement in higher education (Song, 2010). Rowe (2004) suggests that guest speakers enhance student perceptions, make students interested, improve communication skills, develop experiences and provide essential field knowledge required for work. In a research on guest lecturers in higher education conducted by Kumari (2001), the author discovered that by bringing guest speakers into class rooms, student's critical thinking and participation skills are immensely enhanced. Kumari (2001) argued that during the guest speaker's visit to the classroom, student participation peaked. Kumari (2001) suggested that the presence of a guest speaker presenting discussion directly from a field of expertise stimulated students to communicate amongst one another and develop their critical thinking skills. On the contrary, Song (2010) argues that despite their great benefits, guest speakers are difficult to arrange because of certain difficulties such as budgets, availabilities, and travel distances. Mullins (2001) similarly suggests that guest speakers are difficult to arrange as arrangements for guest speakers consist of long and complicated processes which begin by trying to secure the right guest speaker well in advance, providing transport and accommodation, securing the fund- 
ing needed and making sure that the guest speaker relates in his/her discussions to the topics taught in class. Mullins (2001) further discusses the difficulties of guest speakers by stating that guest speakers should be familiar in advance with the teaching styles used in class, with the students being taught and informed about the content of the class and programme. Mullin (2001) argues that the latter needs to be achieved in order to make students feel comfortable with the guest speaker.

Furthermore, Sivan (2000) suggests that the government is now expecting higher education to further develop in order to implement enduring learning strategies and therefore students are being required to be more self-managed. Sivan (2000) then stresses the importance of guest lecturers in higher education as they develop problem solving skills which enable them to become more self-managed. Snyder (2003) related to guest speaker from a different approach. The author highlighted the difficulties that lecturers usually face with students and suggested that guest lecturers provide a more realistic approach that students are interested in. Snyder (2003) argued that learning is risky as students might not participate, and therefore will not develop any skill, which would then lead the lecturer to feeling a loss of control. Snyder (2003) concludes that guest speakers motivate students and encourage their participation in classrooms. Finally, Payne (2003) states that "guest speakers are an effective means to bring the world into the classroom only when company visits cannot be used" (pp.327). Payne (2003) therefore highlights the importance of guest speakers but suggests that they are only a second option after industry and company visits. Thus, Payne implies that students desire the "real" field experience from company representatives more than guest speakers. The author also denotes to the importance of field work and is perceived as an enhanced experience to that of a guest lecturer. Taking
Payne's suggestion into consideration and the literature provided above, a structure of classroom desire by students in classrooms is revealed, making company representatives the most desired and academic lecturers the least favoured. However, from such findings it is also essential to accentuate that lecturers and guest speakers are perceived as two different entities by students, where lecturers are seen as classroom managers and guest speakers are the industry knowledge providers. Student thus feel managed and theoretically educated by the lecturer, whereas the guest speaker is the provider of real life learning and industry knowledge experts.

\section{Guest speakers in Tourism Programmes}

Taking into consideration Payne's suggestion (2003), McKellan (2007) statement regarding students not having the field knowledge required and Ntuli (2007)'s argument concerning students lacking skills, certain points of discussion arise as highlighted below.

\section{The role of universities in higher education}

It is a familiar phenomenon that universities offer a unique experience to students and provide them with academic and theoretical knowledge. Such knowledge then acts as the basis required for the industry, as then a student could apply theory gained in the classroom to the industry directly. If practical experiences were lacking in universities, they are provided in colleges by field experts and not by academics. So if this is what students require, why not opt for college education? Deit (2011) argues that colleges employ large numbers of high-skilled industry workers which deliver programmes to students. Therefore, the lecturer in college encompasses years of field experience which 
they would deliver directly to students. This would then make the presence of a guest speaker unrequired. In Crebert's argument (2004), regarding universities that offer tourism management programmes, Crebert explains that these universities contain the facilities that permit technical skills to be taught to students and applied in workplaces. This is somewhat arguable as not all universities encompass such facilities. Instead, it is colleges that hold such facilities as they tend to focus on experience based teaching, whilst universities focus entirely on theory. This argument derives from a comparison between two British based institutions, Newcastle College and the University of Sunderland, that both offer BSc degrees in Tourism Management. Newcastle College comprises a restaurant, several kitchens, a bistro, a theatre, a model airplane and an information centre, all managed by students across various programmes including Tourism Management students. Such industry related facilities are not included in the University of Sunderland. Experience advocates that colleges are experience-focused and universities are knowledge-focussed. This therefore refers to the original argument: if students desired education from field experts, why not choose colleges?

\section{The role of the lecturer in Tourism Management}

Pintrich and Zusho (2002) state that student learning is an active constructive process whereby learners set goals for their learning and regulate, and control their cognition, motivation, and behaviour, guided and constrained by their goals and the contextual features of the environment. Pintrich and Zusho (2002) therefore suggest that it is a student's responsibility to learn, whether being taught by an experience-driven lecturer or an academic lecturer. The authors further suggest that it is an academic's duty to monitor student's behaviours as academ- ics encompass the knowledge of monitoring students unlike experience derived tutors. The following suggests that academic tutors are essential in delivering tourism management programmes as academic lecturers can provide the theories necessary for the programme and are encompass the ability to monitor and guide students. McCarthy (1996) describes four types of students and refers to them as the 1-Analytic learners (desirers of facts to support their experiences), 2-innovative learners (learn and relate their education to personal experiences), 3- common sense learners (want to lean through experience and undertake various activities to do so), and 4- dynamic learners (instinctive as they search for learning styles, explore, do and feel). Thus, it could be assumed that all four types of learners can exist within one classroom, and it becomes the lecturer's responsibility that all students learn in the style most appropriate to them. Applying all four types of teaching would ensure that all students gain the knowledge required. Moreover, when examining $\mathrm{McCa}$ rthy's (1996) types of learners, it could be argued that all four types of teaching styles are being applied for those learners within the tourism management programmes at universities without having to include a guest lecturer. When looking at "analytic learners", students are being given real life examples in each lecture that support the topic being taught. By examining "innovative learners" it is expected that students discuss their experiences within the classroom and are able to apply the theoretical experiences learnt via the supporting workshops provided. By looking at "common sense learners", universities offering tourism programmes are expected to send students to fieldtrips on a yearly basis. This would help enhance their field-experience. Universities are also expected to provide students an optional work experience gap year, or a compulsory year of industrial placement that academic lecturers supervise and monitor and are improvise by 
the university in cooperation with various organisations. "Dynamic learners" encourages students to opt for their individually required field experiences. They select their topic of interest and decide where to go or travel for their field research, and can select the organisation, city, or area that they would like to conduct their research in. Therefore, providing a more firsthand realistic experience than a guest speaker could ever provide which also gives students the true experience they desire. The latter is more valuable than what experienced guest speaker could bring into a classroom as field experience is gained firsthand rather than being transmitted in the form of information through a third part.

Nevertheless, guest speakers remain an essential component of higher education as they can be the informers of practical experience prior the student gaining practical experience firsthand. Students would then refer to theory provided by the lecturer, followed by the knowledge of the industry provided by the guest lecturer, and can then relate to all information gained while experiencing field work.

\section{Guest speakers and students in Tourism Management}

Immense literature and various authors stress the importance of guest speakers in higher education (Song, 2010; Rowe, 2004; Snyder, 2003; Payne, 2003; Kumari, 2001) and none oppose it or suggest otherwise. Mullins (2001) argues that despite guest speakers having their disadvantages, such as finding it hard to organise guest speakers and they might be costly, guest speaker deliver realistic information based on field experience to students. Guest speakers also provide them with the realities that are not available in textbooks. Mullins (2001) explains how guest speakers can support the material being provided in class and enhance the knowledge that students gain. Thus, guest speakers act as real life knowledge retreaters by providing industrial examples to the theoretical knowledge expressed by lecturers. Laurence (2005) similarly argues that guest speakers provide different essential knowledge to students than the knowledge provided by a lecturer as theirs is experienced based, and suggests that all students value the views and efforts made by guest speakers.

Taking the latter into consideration, an essential question emerges: are guest speakers rationally required in higher education in the $21^{\text {st }}$ century? Does a century that is witnessing educational transformations and is shifting more towards distant learning, online universities, video conference lecturing and online education require guest lecturers? And how do they fit in? If guest speakers were so essential and were necessitated by students, then distant and online education should not be as popular as it is today.

Moreover, higher education and tourism programmes accommodate all genders and different age groups. According to recent research conducted by Universities and Colleges Admission Service (2014), the past few years have witnessed the continuation of a small but steady annual increase in application rates to university from people older than 21. Therefore, more mature students are entering university and pursuing degrees in certain fields including tourism management. Such students might already entail industry knowledge and are in pursuit of pure theoretical based knowledge. Industry based guest speakers might prove non-appealing to such audiences, and might be only of certain appeal to younger students who have no industry experience whatsoever. Taking such factors into consideration, guest speakers become an optional element of higher education, certainly depending on the nature of the programme offered. Looking more closely at tourism programmes, guest speakers become an undesired entity for students already employed in the industry. They pur- 
sue a degree in higher education to deepen their knowledge of the industry based on theory and would then relate it to their experience on an individual level. Long distant and online degrees are created as a means of encouraging students to attain higher education theory based degrees while working within the industry. It encourages them to remain at work and is provided with the theoretical material as a means of independent study in the free time available. It encourages full time commitment to the practical industry by means of remaining at work rather than physically existing in a higher education institution. Practical knowledge is therefore gained independently by the student themselves, while the University would simply act as the provider of theoretical material and the guide of the student.

As universities that host tourism programmes also offer real-life experiences to students by conducting fieldtrips, work placements and provides them with relevant practical workshops, guest speakers become less popular and less desirable now as they perhaps were before. With internationalisation becoming a key emphasis in most governance and strategy discussions, the significance of guest speakers in higher education becomes invaluable.

\section{Internationalisation and guest speakers}

Internationalisation in higher education is perceived and implemented as mainly a luxury addition to teaching and learning and that it is an implicitly natural dimension of research (de Wit, 2013). The consequence of such assumptions about internationalisation is that the funding, support and organisations required to internationalise are a key challenge (Arum and Roksa, 2011). This applies both to teaching and learning, and to research. Faculty engagement, the integration of internationalisation into the curriculum, and the mainstreaming of internationalisation are seen as the main ways to overcome that challenge (Arum and Roksa, 2011).

Moreover, Green and Whitsed (2015) explain that universities see internationalisation of their curricula as a means of preparing their graduates to live and work in a globalised world. The authors suggest there is a considerable variation in the way in which internationalised education is enacted in different regional and national contexts. While growing importance is being attached to incorporating an international dimension into the curriculum, which is also reflected in the European Commission's European Higher Education in the World strategy, operationalization within the institutions remains a challenge. Academic staff may not always understand the meaning of the term, or have the ability or the desire to design and deliver internationalised curricula (Green and Whitsed, 2015).

As internationalisation, which requires faculty engagement and mainstreaming of the curriculum, becoming the focus of higher education and as growing importance is being attached to incorporating international dimensions into curricula universities and their curricula shift towards an international mainstream of teaching which completely disregards local guest speakers. With programmes such as tourism management also shifting towards an international context through the internationalisation of teaching, guest speakers become irrelevant as tourism discusses global happenings rather than tourism in the local region.

\section{Conclusions}

Students will always remain "dynamic learners" as suggested by McCarthy (1996). They will choose what is best for them and will pursue their needs and desires. Students will always set their own goals, learn and 
motivate themselves (Pintrich and Zusho, 2002). Guest speakers discussing real life situations and experiences to students are perhaps interesting to students as the latter would give them an escape from boring theories they listen to for hours in classrooms. But, if academics researched the student preferences between guest speakers and practical experiences gained by fieldtrips, findings and arguments would surely differ. Moreover, should a programme be taught by a field experienced tutors that can only deliver experiences, or should an academic lecturer deliver such programmes, and provide practical experiences with it! Theory in classrooms cannot be avoided as it is the sole and core of education, and when field experience is applied to theory taught in classrooms then education would seem to be more effective. Students are the desirers of reality. Real practical stories can be an appeal. However, theoretical knowledge is also a reality. Theory is required as the basis of knowledge in order to be applied in the related industrial field. Employers seek knowledgeable graduates in a specific field with some basic practical experience. Practical experience gained in the form of knowledge provided in classrooms would then prove irrelevant. Knowledge based on theory, coupled with practice in the industry itself is what employers would find appealing and desirable.

To conclude, it could be argued and suggested that guest speakers are used as a form of entertainment that students find amusing and are satisfied to listen to as they desire escaping boredom in lectures, but are not the solution for perfect academic experiences in higher education in general and specifically in tourism programmes.

\section{References}

Arum, R. \& Roksa, J. (2011). Academically adrift: Limited learning on college campuses. Chicago: University of Chicago Press.

Bacon D. R., Novotny J. (2002). Exploring Achievement Striving as a Moderator of the Grading Leniency Effect, Vol. 24(1), p. 4.

Barrie, S.C. (2006). Understanding what we mean by the generic attributes of graduates. Higher Education, 51, 215-241.

Bligh, D. (1998). What's the Use of Lectures, Second Edition, Intellect, Exeter, pp 10-23.

Byrne, M. (2002). Approaches to learning of European business students, Journal of Further and Higher Education, 26(1), 19-28.

Charlton, J.P. (2006). How human is your computer? Measuring ethopoeic perceptions of computers. In K. Morgan, C.A. Brebbia, \& J.M. Spector (eds.), The Internet Society II: Advances in Education, Commerce \& Governance (pp. 167-176). Southampton: WIT Press.

Coll, R. \& Zegwaard, K.E. (2006). Perceptions of desirable graduate competencies for science and technology new graduates. Research in Science \& Technological Education, 24(1), 29-58.

Crebert, G.(2004). Ivory Tower to Concrete Jungle Revisited. Journal of Education and Work, 17(1), 47-70.

de Wit, H. (2013). Rethinking the concept of internationalisation. In Stiasny, M. \& Gore, T. (eds.). Going Global: Identifying Trends and Drivers of International Education (pp. 213-218). London: Emerald Group Publishing.

Crosby, J. (2000). AMEE Education Guide No 20: The good teacher is more than a lecturer - the twelve roles of the teacher. Medical Teacher 22(4), 334-347.

Fleming, J., \& Eames, C. (2005). Student learning in relation to the structure of the cooperative education experience. Asia-Pacific Journal of Cooperative Education, 6(2), 2631. 
Green, W. and Whitsed, C. (eds.) (2015). Critical Perspectives on Internationalising the Curriculum in Disciplines. Sense Publishers.

Heylings, D., Tariq, N. (2001). Reflection and feedback on learning: a strategy for undergraduate research project work. Assessment and Evaluation in Higher Education 26 (2), 153-64.

Hodges, D. \& Burchell, N. (2003). Business graduate Competencies: Employers' Views on Importance and Performance. Asia-Pacific Journal of Cooperative Education, 4(2), 16-22.

Huxham, M. (2007). Fast and effective feedback: are model answers the answer? Assessment and Evaluation in Higher Education, 32, 601-611.

Johanson, M., Shea, L.J., Ghiselli, R., Roberts, C. (2010). Revealing key competencies of hospitality graduates demanded by industry: A 25 year review. Hospitality and Tourism Management International CHRIE Conference-Refereed track.

Kumari, D. S. (2001). Computer conferencing with access to a 'guest expert' in the professional development of special educational needs coordinators. British Journal of Educational Technology, 35, 11, 81-93.

Ladkin, A., \& Weber, K. (2008). Tourism and hospitality academics: Career profiles and strategies. Journal of Teaching in Travel \& Tourism, 8(4), 373-393.

Lawrence, J. (2005). Addressing diversity in higher education: Two models for facilitating student engagement and mastery, Sydney: Higher Education Research and Development Society of Australasia.

Malley, M. (1997). Institutions searching for perfect blend of faculty. Hotel \& Motel Management, 212(13), 19. Retrieved from Business Source Premier database.

McCarthy, P. (1996). I Like Your Style: The Learning Approaches of Leisure, Tourism and Hospitality Students Studying Generic Modules. Journal of Hospitality, Leisure, Sport and Tourism Education. 5(2).
Moss, S. \& McKellan, S. (2007). Innovative Assessment Strategies for developing Employability Skills in the Tourism and Entertainment Management Curriculum At Leeds Metropolitan University. Paper presented at the 2007 EuroCHRIE Conference, Leeds, UK.

Mullin, P. (2001). Using Outside Speakers in the Classroom. OBSERVER. American Physiological Society.

Ntuli, D. (2007). Graduates fail by degrees. Business Times Careers, April.

Payne B. (2003) Bringing the Field into the Criminal Justice Classroom: Field Trips, Ride-Alongs, and Guest Speakers, Journal of Criminal Justice Education, Vol. 14 (2), p. 327.

Pintrich, P. R., \& Zusho, A. (2002). The development of academic self-regulation: the role of cognitive and motivational factors. In A. Wigfield, \& J. S. Eccles (eds.), Development of achievement motivation (pp. 249-284). San Diego: Academic Press.

Reece, I., Walker, S. (2001). Teaching and Training and Learning: a practical guide, $4^{\text {th }}$ Edition, Sunderland, Business Education Publishers Limited.

Rowe, S. (2004). A case for virtual guest lecturers: the experience of using practitioners in asynchronous discussion forums with an undergraduate auditing class. Australia.

Sivan, A. (2000). An Implementation of Active Learning and its Effect on the Quality of Student Learning, Innovations in Education and Training International, Vol. 37(4), p. 381.

Snyder, K. D. (2003). Ropes, Poles, and Space: Active Learning in Business Education, Active Learning in Higher Education, The Institute for Learning and Teaching in Higher Education and Sage Publications, Vol. 4(2), pp.159-167.

Song, C. (2010). Promoting Student Service Learning through Web Guest Speakers in Distance Education. California.

Tovey, J. (2001). Building connections between industry and university: implementing an 
internship program at a regional university. Technical Communication Quarterly, 10(2), 225-240. UCAS, (2014). University Application Statistics.

https://www.ucas.com/system/files/ucas 2014_application_rate_jan_deadline2.pdf. Last Accessed: 23 January 2016.

Waryszak, R.Z. (1999). Students' expectations from their cooperative education place- ments in the hospitality industry: an international perspective. Education and Training, 41(1), 33-40.

Yorke, M. \& Harvey, L. (2002). Graduate Attributes and Their Development. New Directions for Institutional Research, 128, 41-58. 